\title{
Assessment of the Rationale behind the Concurrent Practice of Conventional and Computed Radiography in Two Federal Hospitals in Maiduguri, Borno state
}

1 Moi Alhamdu

1 Ukeme Pius

2 Dlama Joseph

1 Department of Medical Radiography, University of Maiduguri, Borno State

2 Department of Medical Radiography, Bayero University Kano, Kano State tem could serve as backup in the event of breakdown of one system. Majority $(66.7 \%, n=34)$ agreed that the main disadvantage of the concurrent practice of both radiographic systems was that it was expensive to practice and maintain both systems concurrently. Chi square value was statistically significant $p<0.005$.

Conclusion: The major rationale was preference by referring physicians. The study revealed the advantages of the concurrent practice of both radiographic systems and the provision of a backup system in the event of break down. The disadvantage of the concurrent practice of both radiographic systems is the cost of maintenance and the incidence of undue preference of one radiographic system over another.

Acknowledgement: we acknowledge the management and staff of Radiology departments of the two hospitals where the study took place.

Keywords: conventional radiography, computed radiography, concurrent practice.

Article received: 14.01.2019.

Article accepted: 10.02.2019.

DOI: $10.24141 / 1 / 5 / 1 / 12$

Corresponding author:

Dr Joseph Dlama Zira,

Department of Medical Radiography, Bayero University Kano, Kano State, Nigeria

Phone number +2348130582721

email:josephdlama@gmail.com the main advantage of the concurrent practice of both radiographic systems was that each radiographic sys- 


\section{Authors Contributions}

Moi Alhamdu: Developed the concept and the entire manuscript

Ukeme Pius: Sourced for relevant literature and collected the data and analysed it

Dlama Joseph: Organised the final draft and reviewed the manuscript and submitted for review process

Conflict of Interest: Nil

Funding : Nil

\section{Introduction}

Conventional radiography also known as Screen Film radiography (SFR) is still used more widely than digital radiography but this dominance is fast declining ${ }^{1}$. The reasons behind the declining popularity of SFR are fixed dose latitude, fixed nonlinear grey scale response, images cannot be changed in contrast once they have been processed and limited potential for reducing the dose to the patient ${ }^{1}$. Apart from this, conventional radiography films which must be constantly bought are expensive and hazardous materials are used for processing. Also, long term storage and difficulties with film retrieval are not compatible with the picture archiving and communication systems (PACS) ${ }^{2}$. With recent advances in technology it is now possible to have digital solutions for radiography problems at a cost-effective rate, and also get better image quality in certain applications when compared to SFR ${ }^{3}$. The evolution of medical imaging towards totally digital imaging has accelerated over the past decade ${ }^{4}$.

Digital radiography (DR) is a form of $x$-ray imaging where digital $x$-ray sensors are used instead of traditional films. The exposure is captured in a device that converts the energy of the $\mathrm{x}$-ray to a digital signal, which is then represented on a monitor for viewing and reporting ${ }^{5,13}$.

Computed radiography (CR) is a digital image acquisition and processing system for radiography that uses computers and laser technology ${ }^{1,6}$. It is a digital imaging system which exposes a photostimulable phosphor image receptor plate to obtain a latent image using existing conventional radiographic equipment. The image is read by a laser device and converted from analogue to digital data by a computer. The digital image can then be processed and viewed on a video display terminal or film ${ }^{1,12}$

It is becoming obvious that there is a wide acceptability of digital radiography over conventional radiography as most radiology departments are acquiring new digital radiography equipment increasingly ${ }^{2,11}$. This might be due to the numerous technological benefits, image post processing abilities, good workflow and other advantages that $\mathrm{DR}$ offers in a constantly technologically innovating world. But still, radiology departments who have acquired digital radiography are practicing it concurrently with conventional radiography ${ }^{10}$.

Although computed radiography equipment was designed to retrofit unto existing conventional radiography equipment, both radiographic systems are often practiced concurrently ${ }^{1,7}$. Most radiology departments in Africa still practice computed and conventional radiography concurrently ${ }^{8}$.

It has been observed that some radiology departments practice conventional and computed radiography concurrently without any established rationale behind such practice. This study was therefore designed to establish the rationale behind such practices, its advantages and disadvantages in the radiology departments of University of Maiduguri Teaching Hospital and Federal Neuropsychiatric Hospital Maiduguri.

\section{Materials and methods}

This study is a prospective cross-sectional survey conducted in two hospitals: University of Maiduguri Teaching Hospital (UMTH) and Federal Neuropsychiatric Hospital (FNPH) Maiduguri, Borno state. After due consent from each respondents, data were obtained primarily through semi-structured, self-completed questionnaires which were administered to radiologists, radiographers and intern radiographers in the study areas. The questionnaire is a 22-item form divided into four sections, Section A: Demographic data, Section B: Rationale for concurrent practice of computed radiography and conventional radiography, Section C: merits of concurrent practice of computed radiography and 
conventional radiography and Section D: demerits of concurrent practice of computed radiography and conventional radiography.

Eligibility criteria includes radiologists, practicing radiographers and intern radiographers, who had at least 3 months of working experience at the study site. Descriptive statistics was generated from the data collected using Microsoft Excel version 2010. Results of inferential statistics (Chi-square) were computed using statistical software called Statistical package for Social Sciences (SPSS), Version 19.0 and statistical significance was set at $\mathrm{p}<0.05$.

Ethical clearance was obtained from the health research ethics committee of the hospitals.

\section{Results}

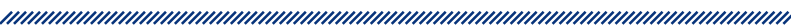

\begin{tabular}{|c|c|}
\hline \multicolumn{2}{|l|}{ Test Statistics } \\
\hline Item & Value \\
\hline Chi-square $\left(X^{2}\right)$ & 14.294 \\
\hline Degree of freedom & 1 \\
\hline $\begin{array}{l}\text { Critical chi-square table value at } 1 \text { degree of } \\
\text { freedom at } 0.05 \text { level of significance }\end{array}$ & 3.841 \\
\hline
\end{tabular}

Table 2 shows that 51 staff (radiologist, radiographers and intern radiographers) of radiology departments of UMTH and FNPH participated in the study. There were $46(90.2 \%)$ staff from UMTH and $5(9.8 \%)$ staff from FNPH. There were $33(64.7 \%)$ males and $18(35.3 \%)$ female respondents.

\begin{tabular}{|c|c|c|c|c|}
\hline$\overline{S / N}$ & Responses & Variables & Frequency & Percentage $(\%)$ \\
\hline \multirow[t]{3}{*}{$\mathrm{i}$} & Institution & UMTH & 46 & 90.2 \\
\hline & & FNPH & 5 & 9.8 \\
\hline & & Total & 51 & 100.0 \\
\hline \multirow[t]{3}{*}{ ii } & Gender & Male & 33 & 64.7 \\
\hline & & Female & 18 & 35.3 \\
\hline & & Total & 51 & 100.0 \\
\hline \multirow[t]{6}{*}{ iii } & Age & 20-26 years & 5 & 9.8 \\
\hline & & 27-33 years & 29 & 56.9 \\
\hline & & $34-40$ years & 11 & 21.6 \\
\hline & & 41-47 years & 1 & 2.0 \\
\hline & & 48 years and above & 5 & 9.8 \\
\hline & & Total & 51 & 100.0 \\
\hline \multirow[t]{4}{*}{ iv } & Designation & Radiologist & 14 & 27.5 \\
\hline & & Radiographer & 25 & 49.0 \\
\hline & & Intern Radiographer & 12 & 23.5 \\
\hline & & Total & 51 & 100.0 \\
\hline \multirow[t]{5}{*}{$\mathrm{v}$} & Years of working experience & less than a year & 12 & 23.5 \\
\hline & & 1 year & 9 & 17.6 \\
\hline & & 1-10 years & 29 & 56.9 \\
\hline & & 21 years and above & 1 & 2.0 \\
\hline & & Total & 51 & 100.0 \\
\hline \multirow[t]{2}{*}{ vi } & $\begin{array}{l}\text { You have worked with conventional and computed } \\
\text { radiography concurrently. }\end{array}$ & $\begin{array}{l}\text { Agreed } \\
\text { Disagreed }\end{array}$ & $\begin{array}{c}51 \\
0\end{array}$ & $\begin{array}{c}100.0 \\
0\end{array}$ \\
\hline & & Total & 51 & 100.0 \\
\hline vii & $\begin{array}{c}\text { If you agree with statement } 6 \text { above, how long have } \\
\text { you worked with both systems? }\end{array}$ & $\begin{array}{c}\text { 3-6 months } \\
1 \text { year } \\
2 \text { years } \\
3 \text { years } \\
\text { Total }\end{array}$ & $\begin{array}{c}12 \\
3 \\
10 \\
26 \\
51\end{array}$ & $\begin{array}{c}23.5 \\
5.9 \\
19.6 \\
51.0 \\
100.0\end{array}$ \\
\hline
\end{tabular}


In all, there were 14 (27.5\%) radiologists: 12 (85.7\%) from UMTH and 2 (14.3\%) from FNPH, 25 (49.0\%) radiographers: 22 (88\%) from UMTH and 3 (12\%) from FNPH and $12(23.5 \%)$ intern radiographers from UMTH. At the period of the study there were no intern radiographers in $\mathrm{FNPH}$.

Majority of the respondents (29) were between the age range of 27-33 years while only 1 respondent with the least frequency was between the age range of 41-47 years. With respect to the years of working experience, majority of the respondents (29) had working experience of 1-10 years and only 1 respondent had working experience of 21 years and above. All the respondents agreed to have worked with conventional and computed radiography concurrently. Twenty- six (51.0\%) respondents representing the highest frequency had worked with both radiographic systems for a period of 3 years while 12 respondents representing the lowest frequency had worked with both radiographic systems for a period between 3-6 months only.

Based on the awareness of the rationale behind the concurrent practice of conventional and computed radiography, 39 respondents (76.5\%) agreed that there were rationales behind the concurrent practice of both radiographic systems in their department while 12 $(23.5 \%)$ respondents disagreed. Thirteen $(n=13,25.5 \%)$ respondents agreed that both radiographic systems were used concurrently while 38 (74.5) respondents disagreed. Thirty-seven $(n=37,72.5 \%)$ respondents agreed that both radiographic systems were used concurrently while $14(27.5 \%)$ disagreed. Sixteen $(n=16 ; 31.4 \%)$ respondents agreed that the incidence of preference of one radiographic system over the other by referring physicians was the rationale for the concurrent practice of both radiographic systems in their department while 35 (68.6\%) disagreed. Only 4 (7.8\%) respondents agreed that the rationale behind the concurrent practice of both radiographic systems in their department was that each system served entirely different diagnostic purposes while the majority, 47 (92.2\%) disagreed. Twenty-seven (27) respondents (52.9\%) agreed that the rationale behind the concurrent practice of both radiographic systems in their department was so that patients could be at liberty to choose the services of the system they could afford while 24 (47.1\%) disagreed.

With respect to the advantages of the concurrent practice of conventional and computed radiography, 45 $(88.2 \%)$ respondents agreed that there were advantages in the use of both radiographic systems while 6 $(11.8 \%)$ respondents disagreed. Thirty-eight $(n=38$, $74.5 \%)$ respondents agreed that the concurrent practice of both radiographic systems had led to the division of labour in their department while $13(25.5 \%)$ respondents disagreed.

\begin{tabular}{|c|c|c|c|c|}
\hline $\mathrm{S} / \mathrm{N}$ & Responses & Variables & Frequency & Percentage (\%) \\
\hline $\mathrm{i}$ & $\begin{array}{c}\text { There are established reasons for the concurrent } \\
\text { practice of both radiographic systems }\end{array}$ & $\begin{array}{l}\text { Agreed } \\
\text { Disagreed } \\
\text { Total }\end{array}$ & $\begin{array}{l}39 \\
12 \\
51\end{array}$ & $\begin{array}{c}76.5 \\
23.5 \\
100.0\end{array}$ \\
\hline ii & $\begin{array}{c}\text { Both radiographic systems are used merely because } \\
\text { they are both present and in good functioning } \\
\text { condition. }\end{array}$ & $\begin{array}{l}\text { Agreed } \\
\text { Disagreed } \\
\text { Total }\end{array}$ & $\begin{array}{l}13 \\
38 \\
51\end{array}$ & $\begin{array}{c}25.5 \\
74.5 \\
100.0\end{array}$ \\
\hline iii & $\begin{array}{l}\text { Both systems are used concurrently because such } \\
\text { practice aids in division of labour. }\end{array}$ & $\begin{array}{l}\text { Agreed } \\
\text { Disagreed } \\
\text { Total }\end{array}$ & $\begin{array}{l}37 \\
14 \\
51\end{array}$ & $\begin{array}{l}72.5 \\
27.5 \\
100\end{array}$ \\
\hline iv & $\begin{array}{c}\text { Both radiographic systems are concurrently used } \\
\text { because there is preference of either radiographic } \\
\text { system by referring doctors. }\end{array}$ & $\begin{array}{l}\text { Agreed } \\
\text { Disagreed } \\
\text { Total }\end{array}$ & $\begin{array}{l}35 \\
16 \\
51\end{array}$ & $\begin{array}{l}68.6 \\
31.4 \\
100\end{array}$ \\
\hline v & $\begin{array}{c}\text { Both radiographic systems are concurrently used } \\
\text { because they serve entirely different diagnostic } \\
\text { functions. }\end{array}$ & $\begin{array}{l}\text { Agreed } \\
\text { Disagreed } \\
\text { Total }\end{array}$ & $\begin{array}{l}4 \\
47 \\
51\end{array}$ & $\begin{array}{c}7.8 \\
92.2 \\
100.0\end{array}$ \\
\hline vi & $\begin{array}{c}\text { Both radiographic systems are concurrently used so } \\
\text { that patients are at liberty to choose which system } \\
\text { they can afford to pay for. }\end{array}$ & $\begin{array}{l}\text { Agreed } \\
\text { Disagreed } \\
\text { Total }\end{array}$ & $\begin{array}{l}27 \\
24 \\
51\end{array}$ & $\begin{array}{c}52.9 \\
47.1 \\
100.0\end{array}$ \\
\hline
\end{tabular}




\begin{tabular}{l} 
Table 4. Advantages of the concurrent practice of conventional and computed radiography in \\
UMTH and FNPH \\
\hline S/N
\end{tabular}

Forty $(n=40,78.4 \%)$ respondents agreed that the advantage of the concurrent practice of both radiographic systems was that it made their department efficient and effective in the management of a wide range of diagnoses while $11(21.6 \%)$ disagreed. Thirty-two $(n=32$, $62.7 \%$ ) respondents agreed that the advantage of the concurrent practice of both radiographic systems was that it allowed radiology staff who did not have computer knowledge applied in computed radiography to still be useful in the department while 19 (37.3\%) respondents disagreed.

With respect to the disadvantages of the concurrent practice of conventional and computed radiography, 36 (70.6\%) respondents agreed that there were disadvantages in the use of both radiographic systems while 15
(29.4\%) respondents disagreed. Thirty-four (34) (66.7\%) respondents agreed that the disadvantage of the concurrent practice of both radiographic systems was that it was expensive to use and maintain both systems concurrently while 17 (33.3\%) disagreed. Sixteen (31.4\%) respondents agreed that the disadvantage of the concurrent practice of both radiographic systems was that there was incidence of undue preference of one radiographic system over the other by referring physicians.

\begin{tabular}{l} 
Table 5. Disadvantages of the concurrent practice of conventional and computed radiography \\
in UMTH and FNPH. \\
\hline S/N
\end{tabular}




\section{Discussion}

From the results of this study, Table 1 showed that the calculated chi-square value (14.294) is greater than the critical table value (3.841), therefore we reject the null hypothesis and accept the alternative hypothesis which states that: There are rationales behind the concurrent practice of conventional radiography and computed radiography at the radiology departments of UMTH and FNPH, Borno State.

Table 3 showed that there were sixteen $(n=16,31.4 \%)$ respondents who agreed that the incidence of preference of one radiographic system over the other by referring physicians was the rationale for the concurrent practice of both radiographic systems in their department while $35(68.6 \%)$ disagreed. This is in line with the findings of Dlam-Da (2009), who reported that the one of main reasons for using both radiographic systems was the preference of $\mathrm{CR}$ over conventional radiography by referring physicians ${ }^{8}$. This implies that there were existing reasons for the practice of both radiographic systems ${ }^{8}$.

Only 4 (7.8\%) respondents agreed that the rationale behind the concurrent practice of both radiographic systems in their department was that each system served entirely different diagnostic purposes while the majority, $47(92.2 \%)$ disagreed. This finding concurs with the findings of Dlam-Da (2009) who reported that although conventional and computed radiographic systems operate on seemingly different principles, they do not serve different diagnostic purposes ${ }^{8}$.

Twenty-seven (27) respondents (52.9\%) agreed that the rationale behind the concurrent practice of both radiographic systems in their department was so that patients could be at liberty to choose the services of the system they could afford while 24 (47.1\%) disagreed. This finding disagree with the findings of Dlam-Da (2009) who reported that one of the main reasons for the simultaneous practice of screen film radiography and computed radiography was so that patients could choose which systems they were able to pay for ${ }^{8}$.

Forty-five (45) respondents agreed that the advantage of the concurrent practice of both radiographic systems was that each radiographic system could serve as backup in the event of breakdown of one system. The findings of this study agree with the finding of Dlam-da (2009) who reported that screen film radiography and computed radiography were used simultaneously in his study area so that each radiographic system can serve as backup in the event of breakdown ${ }^{8}$. With respect to the disadvantages of the concurrent practice of conventional and computed radiography, 36 (70.6\%) respondents agreed that there were disadvantages in the practice of both radiographic systems while 15 (29.4\%) respondents disagreed. This finding is in agreement with that of Dlam-Da (2009) ${ }^{8}$.

Thirty-four ( $n=34,66.7 \%$ ) respondents agreed that the disadvantage of the concurrent practice of both radiographic systems was that it was expensive to use and maintain both systems concurrently while 17 (33.3\%) disagreed. This finding is in agreement with that of Dlam-Da (2009) who reported that the main advantage of the practice of simultaneous SFR and computed radiography was the cost incurred in maintenance ${ }^{8}$.

Sixteen $(n=16,31.4 \%)$ respondents agreed that the disadvantage of the concurrent practice of both radiographic systems was that there was incidence of undue preference of one radiographic system over the other by referring physicians. The finding of this study agrees with the finding of Dlam-da (2009) who reported that the demerit of such practice was the incidence of undue preference by referring physicians ${ }^{8}$. This could have been due to the perceived high image quality and contrast of $\mathrm{CR}$ over conventional radiography by the referring physicians ${ }^{10,12}$. The study found out that the main reasons for the simultaneous practice of screen film radiography and computed radiography, despite the various research proven superiority of CR to SFR, included: preference of referring physician, challenges of computer knowledge needed in computed radiography for computer illiterate and the patient's ability to afford the cost of either of the systems ${ }^{8,11}$. The study also revealed that there were advantages and disadvantages of using both systems ${ }^{8}$. The main advantages were: effectiveness and efficiency in diagnosis, provision of backup mechanism in the event of breakdown ${ }^{8}$. The main disadvantage of such practice was the high cost of the maintenance of both radiographic systems ${ }^{8}$.

The Discussion section should be rewritten, because marked sentences from the Results section should be adequately inserted and commented with appropriate references signed at the end of the paragraph. 


\section{References}

1. Polunin, N., Lim T., and Tan K. Reduction in retake rates and radiation dosage through computed radiography. Ann Acad Med, 1998; Singapore. 807.

2. Bansal J. Digital radiography, a comparison with modern conventional imaging. Post graduate Medical Journal, 2006; 82: 425-428. Available at: http://www.ncbi.nlm. nih.gov/pmc/articles/PMC2563775/ [Accessed 10 $10^{\text {th }}$ December 2014].

3. Silva D. Comparative study between conventional and digital radiography in cephalometric analysis. Journal of Health Sciences Institute. February; 2011, 29: 19-22.

4. Pongnapang, N. Practical guidelines for radiographers to improve computed radiography image quality. Biomedical imaging and Interventional Journal, 2005, 1:12 Available at [Accessed $16^{\text {th }}$ October 2012].

5. Hoines C. Digital Radiography: the difference between CR and DR Veterinary X-ray systems. 2013, Available online at: (http://www.uk-ireland.bcftechnology.com/ blog/2013/april/digital-radiography-the-differencesbetween-cr-and-dr-veterinary-x-ray-systems). [Accessed $7^{\text {th }}$ April 2015].

6. Novograd, D. Gale Encyclopaedia of Nursing and Allied Health. Available at: (www.ask.com/health/directory/ consumer-encyclopedias-nursing). 2002, [Accessed $14^{\text {th }}$ December 2014].

7. Dlam-Da Y., Chimum C and Deago U. Evaluation of rationale for the simultaneous practice of screen film radiography and computed radiography at Al-Badan Specialist Hospital. Journal of Radiology. 2009, Available online at www.ccpsradiol.org, [Accessed $7^{\text {th }}$ April 2015].

8. Dwyer, J. Imaging system architecture for picture archiving and communication systems. Radiology Clinic North America, 1996: 495.

9. Agthe P. Contrasting Views - Digital vs. conventional radiography. Veterinary Times. 2008: 12. 67-72.

10. Agwu K. An evaluation of archival quality of radiographs in Nigeria. The official journal of the Australian Institute of Radiography, 1997: 45(2). Available at: http://search. informit.com.au/documentsummary. [Accessed $10^{\text {th }}$ December 2014].

11. Avner A. Computed Radiography, Moving with the time. Available online at: www.chavatdaat.co.il/loadedfiles/ presentation\%20CR.pdf, 2011, [Accessed $16^{\text {th }}$ April 2015].

12. Brown J. How to write a Rationale. Saginaw Valley State University. Available online at: www.ncte.org/library/ NCTEFiles/Involved/Action/Rationale_HowtoWrite. pdf1994, [Accessed 13 ${ }^{\text {th }}$ April 2014]. 


\section{PROCJENA RAZLOGA ZA ISTODOBNU UPOTREBU KONVENCIONALNE I RAČUNALNE RADIOGRAFIJE U DVIJE SAVEZNE BOLNICE U MAIDUGURIJU U SAVEZNOJ DRŽAVI BORNO}

1 Moi Alhamdu

1 Ukeme Pius

2 Dlama Joseph

1 Zavod za medicinsku radiografiju, Sveučilište Maiduguri, Borno State

2 Zavod za medicinsku radiografiju, Sveučilište Bayero Kano, država Kano visok trošak primjene i održavanja dvaju sustava istodobno. Vrijednost hi-kvadrata bila je statistički značajna $\mathrm{p} p<0,005$.

Zaključak: Glavni razlog za upotrebu obaju sustava bila je sklonost liječnika jednom od ta dva sustava. Istraživanje je otkrilo prednosti istodobne upotrebe obaju radiografskih sustava i osiguravanje rezervnog sustava u slučaju kvara. Nedostatak je istodobne upotrebe obaju radiografskih sustava trošak održavanja i neopravdana preferencija jednog radiografskog sustava u odnosu na drugi.

\section{Sažetak}

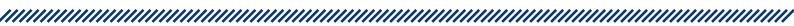

Cilj: Utvrditi razloge za istodobnu upotrebu konvencionalnog i računalnog radiografskog sustava u dvije savezne bolnice te utvrditi njihove prednosti i nedostatke.

Metodologija: Radiolozima, radiološkim tehnolozima i stažistima podijeljen je 51 upitnik od 22 tvrdnje koji se sastoji od četiri dijela. Analiza je provedena primjenom Statističkog paketa za društvene znanosti (SPSS), verzija 19.0. Za testiranje hipoteze primijenjen je hi-kvadrat test $s$ razinom značajnosti od $p<0,05$.

Rezultati: Većina ispitanika $(68,6 \%, n=35)$ složila se da je liječnikova preferencija jednog radiografskog sustava glavni razlog za istodobnu upotrebu obaju radiografskih sustava na njihovim odjelima. Većina $(88,2 \%$, $n=45)$ se složila da je glavna prednost istodobne upotrebe obaju radiografskih sustava da svaki od njih može poslužiti kao rezervni u slučaju kvara jednog od sustava. Većina $(66,7 \%, n=34)$ se složila da je glavni nedostatak istodobne upotrebe obaju radiografskih sustava
Ključne riječi: konvencionalna radiografija, računalna radiografija, istodobna upotreba 